\title{
RANKL EXPRESSION AND METABOLIC CHANGES IN OVARIECTOMIZED RATS AND THE POSSIBLE PROTECTION BY VEGETABLE FORMULA
}

\author{
FAWZY EL- SHOBAKY ${ }^{1}$, SEHAM S. KASSEM ${ }^{1}$, EMTENAN,M. HANAFI ${ }^{2 *}$, MOETAZZA M. AL SHAFEI ${ }^{1}$, \\ ZEINAB A. SALEH ${ }^{1}$, IBRAHIM BADAWY ${ }^{1}$, MADEHA, M. ABD EL KADER ${ }^{1}$
}

${ }^{1}$ Department of Food Science and Nutrition, National Research Center, Dokki, Giza, Egypt. Department of Animal Reproduction and A.I., National Research Center, Dokki, Giza, Egypt. Email: Emtenan_28862@hotmail.com

Received: 15 August 2017, Revised and Accepted: 23 October 2017

ABSTRACT

Objective: This study was to evaluate complications of osteoporosis in ovariectomized rats and the possibility to ameliorate these changes by consumption of vegetable formula. Furthermore, transcription of mRNA of RANKL gene was matched with bone mass density (BMD) and bone formation marker (human procollagen $1 \mathrm{~N}$ terminal peptide [PINP]).

Methods: Thirty rats were divided into three groups. The first is non ovariectomized control group (NOVXC), the second is ovariectomized control group (OVXC), and the third is ovariectomized rats supplemented with the vegetable formula (OVXT). Animals were fed for 8 successive weeks. Animals were treated and sacrificed under the recommended ethics of laboratory animal's treatment. The vegetable mixture was formulated with the purpose to correct the bone compromise and supply all the presumed deficient elements and hormone.

Results: Chemical analysis showed that the formulated vegetable mixture had a high amount of flavonoids as catechin (100 mg/100 g of dry weight) and polyphenols as tannic acid $(1000 \mathrm{mg} / 100 \mathrm{~g}$ dry weight. Furthermore, it had high reducing power (1,1-diphenyl-2-picrylhydrazyl radical showed inhibition percentage of $91.81 \%$.). Several phytochemicals necessary for bone health were demonstrated in the vegetable mixture using highperformance liquid chromatography. RANKL/GAPDH mRNA transcription ratio showed marked an increase in OVXC versus the control NOVXC rats (1.00 vs. 0.199 , respectively) accompanied with a drop in BMD ( 0.157 vs. $0.25 \mathrm{mg} / \mathrm{cm}^{2}$, respectively) and PINP values (27.9 \pm 2.8 compared to NOVXC $34 \pm 2.4 \mu / \mathrm{L}$, respectively). The vegetable mixture supplementation showed better values of BMD and PINP in OVXT group directed back toward normal $\left(0.183 \mathrm{mg} / \mathrm{cm}^{2}\right.$ and $29.35 \pm 3.4 \mu / \mathrm{L}$, respectively). Furthermore, analysis of blood plasma of supplemented group showed lower blood glucose, lipid profile, and oxidative markers if compared to that in OVXC group.

Conclusion: It may be concluded that the plant formula was effective to minimize health hazards in ovariectomized rats and maybe for postmenopause women. Perhaps longer time may be needed for more significant and clear effect.

Keywords: Ovariectomy, RANKL, Bone mineral density, Bone formation marker and vegetables.

(C) 2018 The Authors. Published by Innovare Academic Sciences Pvt Ltd. This is an open access article under the CC BY license (http://creativecommons. org/licenses/by/4. 0/) DOI: http://dx.doi.org/10.22159/ajpcr.2018.v11i1.22020

\section{INTRODUCTION}

Osteoporosis is a major public health issue leads to pain, functional limitation, higher probability of fracture and death especially in postmenopausal women [1]. Lack of estrogen, hyperthyroidism, immobilization, deficiency of vitamins and minerals, elevation of cytokines due to chronic inflammatory disease and oxidative stress play an important role in the pathogenesis of osteoporosis [2]. Osteoprotegerin (OPG) and RANKL are bone-specific genes. RANKL is 317 amino acid peptide [3]. Its major role in bone is the stimulation of osteoclasts differentiation [4], activity and inhibition of osteoclasts apoptosis [5]. The RANKL/RANK signaling pathway has an effect on cytokines such as interleukin (IL)-1, IL-6, and tumor necrosis factor- $\alpha$ and that is why cytokines play a role in the regulation of bone resorption [6]. Studying mRNA transcription of one or both of these genes is helpful to follow-up the process of osteogenesis. It was found that OPG mRNA decreased and RANKL mRNA increased in ovariectomized rats. Estrogen supplementation in such rats elevated the expression of OPG mRNA and suppressed the RANKL mRNA, thus minimizing osteoclastic activity [7]. The common manifestation of osteoporosis is the fragility fracture which affects the quality of life and add more financial burden [8]. Thus, it is important to define the factors contributing to the development of osteoporosis and try to provide the patient with the supplement that enables him to withstand the condition with minimal side effects or complications and in the same time help in osteogenesis.
There is increasing evidence suggesting a positive association between intake of vegetables and bone health as they are major source of antioxidant and anti-inflammatory compounds so that, they regulate the cytokines and control ROS elevation [9]. In the same time, phytoestrogens (isoflavones) is a popular natural compound used as an alternative to estrogen replacement therapy for prevention and treatment of osteoporosis [10]. Cauliflower, turnip, Allium cepa, parsley, spinach, and wild leek have high nutritive values such as Vitamin A, thiamine, riboflavin, niacin, Vitamin $\mathrm{C}$ and minerals such as calcium, iron, phosphorous, and traces such as zinc and selenium [11]. Furthermore, they contain polyphenols, flavonoids, kaempferol, quercetin, and their glycosides [12,13].

Soya bean phytochemicals showed positive linear correlation to antioxidant activity [14]. Isoflavones found in soybeans have a positive effect on estrogen receptors. It can be helpful for treatment of osteoporosis, and menopausal symptoms [15].

\section{Objectives}

The aim was first, to study the effect of ovariectomy on RANKL gene expression, bone mineral density, bone formation marker and other associated biochemical changes in minerals, blood sugar level, oxidative status, and lipid profile. The second objective was to formulate a novel vegetable and soybean mixture to fulfill the requirement for healthy bone and control the deterioration of bone mass in the ovariectomized rats. 


\section{METHODS}

\section{Diet formulation}

Vegetables (cauliflower, turnip, A. серa, parsley, spinach, and wild leek) were purchased from local market, washed, sliced into small pieces and dried in air oven at $60^{\circ} \mathrm{C}$ till complete dryness. Weighed and ground into fine powder. White skimmed unsalted cheese (karish) was dried in air oven at $60^{\circ} \mathrm{C}$ till complete dryness then mixed with ground soya bean and added to the previously mentioned vegetable mixture. All ingredients of this formula were mixed in equal weights and refrigerated until use. It was added to rat basic diet (Table 1) as an additive $(20 \%$ on the expense of starch)

\section{Chemical analysis of the vegetable mixture}

The formula was analyzed for total isoflavonoids as catechin [11], total polyphenols as tannic acid [17], and total antioxidant (TAO) capacity (TAC) (1,1-diphenyl-2-picrylhydrazyl radical [DPPH]) [18]. The phenolic compounds of the mixture were extracted by methanol, and some of these active compounds were identified using highperformance liquid chromatography (HPLC).

\section{Experiment}

Thirty female Sprague Dawley rats (200-250 g body weight) were obtained from the animal house of the National Research Center. Animals were treated according to the known ethical approval for laboratory animals. 20 animals were surgically bilaterally ovariectomized according to Khajuriam et al. [19] while the skin of other 10 animals has been surgically incised without ovariectomy (Sham operation). All animals were acclimatized at room temperature and given control diet for 2 weeks till complete healing of the surgical wound. Animals were divided into three groups (10 each). The first group, which had the Sham operation, was considered as control (non ovariectomized control group [NOVXC]). The second group is considered as ovariectomized control rats (OVXC). Both control groups were fed on control diet (Table 1). The last group (OVXT) was fed on a diet similar to control one, but $20 \%$ of the starch was replaced by the vegetables mixture for 8 successive weeks. At the end of the experiment period, animals were fasted overnight and sacrificed. Blood samples were collected into three different tubes. The first was collected on EDTA and kept in $-80^{\circ} \mathrm{C}$ till be used for RNA extraction and preparation of cDNA which was kept in $-20^{\circ} \mathrm{C}$ till further mRNA transcription of RANKL gene assay. The second blood sample was collected on sodium citrate, for rapid analysis of blood sugar. The last blood sample was collected on EDTA, for separation of plasma and determination of $\mathrm{Ca}, \mathrm{ph}, \mathrm{Mg}, \mathrm{Zn}$, cholesterol, high-density lipoprotein (HDL), low-density lipoprotein (LDL), triglyceride, malondialdehyde (MDA), TAO, and bone formation marker (human procollagen $1 \mathrm{~N}$ terminal peptide [PINP]). The rats' carcasses were frozen in a certain position to evaluate the bone mass density (BMD) by DEXA scan.

\section{Analysis}

Plasma calcium [20], phosphorus [21], magnesium [22], zinc [23], glucose and cholesterol [24], LDL [25], HDL [26], triglycerides [27], MDA [28], and TAC [29] were estimated using colorimetric method commercial kits from Biodiagnostic Egypt.

Table 1: Composition of control diet [16]

\begin{tabular}{ll}
\hline Ingredients & Percentage \\
\hline Casein & 10 \\
Cellulose & 10 \\
Corn oil & 10 \\
Slat mixture & 4 \\
Vitamin mixture & 1 \\
L-cystine & 0.018 \\
Choline chloride & 0.025 \\
Corn starch & 64.957 \\
\hline
\end{tabular}

Serum PINP bone formation marker was performed using Eliza Kit Glory Science Co., Ltd, USA [30].

BMD was estimated using dual-energy X-ray absorptiometry scan DEXA (Lunar DPX DXA system manufactured by GE Health care). All the skeleton of rats was scanned, and the average BMD of each group was estimated.

\section{Gene mRNA transcription quantification}

Rats RANKL and GAPDH mRNAs were semi-quantified by RT-PCR kits. Blood total RNA was extracted using IQeasy TM plus blood RNA extraction mini kit [31]. Taq DNA polymerase was supplied by Invitrogen ${ }^{\circledR}$ (Carlsbad, CA, USA). ReverTraAce ${ }^{\circledR}$ Random primers [32], forward and reverse primers and the product size of the genes were as follows: RANKL, $5^{\prime}$-AGC GTC GCC CTG TTC TTC TAT TT- $3^{\prime} / 5^{\prime}$-ACT TGG GAT TTT GAT GCT GGT TTT-3', 441 bp; and GAPDH, 5'-TCC ACT CAC GGC AAA TTC AAC G/TAG ACT CCA CGA CAT ACT CAG C-3' 145 bp. All chemicals were of the highest available purity from commercial suppliers.

RNA product was reverse transcribed using ReverTra Ace ${ }^{\circledR}$, and then cDNA was amplified under the conditions recommended by the supplier (Invitrogen ${ }^{\circledR}$ ). Real-time analysis was performed using qPCR Green Master (Jena Bioscience) using the fluorescent DNA stain Eva Green ${ }^{\circledR}$.

\section{Statistical analysis}

Results were analyzed by one-way analysis of variance followed by least significant difference post hoc test (SPSS ver. 17.0). $\mathrm{p} \leq 0.05$ was considered statistically significant.

\section{RESULTS AND DISCUSSION}

Evaluation of the RANKL/GAPDH mRNA transcription ratio showed a marked increase in ovariectomized rats (OVXC) versus the control (NOVXC) group (1.00 vs. 0.199 , respectively). Supplementing rats with the formula in OVXT group lowered the mRNA expression of RANKL and controlled bone deterioration and consequently led to controlled osteoporosis on a molecular level (0.51).

The receptor activator of RANKL/RANK/OPG system regulates bone cell function [33]. It was shown that RANKL/RANK signaling regulates the formation of multinucleated osteoclasts, activating and keep it survived. The role of OPG is critical in the protection of the skeleton from excessive bone resorption, and this is accomplished by binding to RANKL and preventing it from binding to its receptor, RANK. Unless RANKL is blocked by OPG in the preosteoblastic/stromal cells, RANKL will bind its receptor RANK on osteoclasts lineage cells, and the differentiation of osteoclasts precursor into mature osteoclasts is accelerated [34].

Results showed a marked drop in BMD values of OVXC compared to NOVXC group ( 0.157 vs. $0.25 \mathrm{mg} / \mathrm{cm}^{2}$, respectively). Rats given the vegetable formula with the diet (OVXT) showed a relatively high BMD value $\left(0.183 \mathrm{mg} / \mathrm{cm}^{2}\right)$ compared with those not given the formula (OVXC).

In the same time, serum level of PINP revealed a significant drop in OVXC group compared to NOVXC $(27.9 \pm 2.8$ and $34 \pm 2.4 \mu / \mathrm{L}$, respectively). Supplementing the plant formula in OVXT showed relatively higher value toward normal $(29.35 \pm 3.4 \mu / \mathrm{L})$. These results of PINP coincide with that of BMD. This can be explained in the light of the absence of estrogen due to ovariectomy and the elevated RANKL mRNA expression that promotes osteoclastic activity in bone [7]. The formula succeeded to control this process to some extent. Perhaps, prolongation of the treatment period would give better effect, and this may be attributed to several factors achieved by the formula. The presences of phytoestrogens in soybeans included in this formula were previously reported to improve bone health and menopausal symptoms [35]. In the same time, the chemical analysis of the supplemented diet showed a high content of isoflavonoids as catechin $(100 \mathrm{mg} / 100 \mathrm{~g}$ 
of dry weight) and polyphenols as tannic acid (1000 mg/100 g dry weight). Furthermore, the TAO was high (estimated by DPPH method which showed inhibition percentage of $91.81 \%$ ).

The HPLC results of the current formulation (Table 2) revealed the presence of important polyphenols necessary for bone health.

These polyphenols and the high antioxidant power of the formula are considered an essential factor is contributing to its effective role in counteracting the drop in BMD due to ovariectomy. It has been reported that the presence of compounds having antioxidant power in food can ameliorate the damaging effects of free radicals and in turn oxidative stress thereby prevent the risk of osteoporosis in postmenopausal women [36].

Results showed (Table 3) that the level of calcium, phosphorus, magnesium, and zinc of OVXC rats was all lower than corresponding levels in NOVXC ones. Addition of the formula to the diet of the OVXT rats relatively improved the level of some of these minerals if compared to OVXC group.

It is well known that calcium, magnesium, zinc and phosphorus participate in the process of collagen, and other proteins essential for bone formation [37]. These minerals are usually found low in menopausal women, and this occurs due to ovarian hormone deficiency [38]. These minerals participate in the process of bone maintenance through their catalytic action in the synthesis of the bone matrix [39]. It is clear that the body under such condition is in need to replenish these minerals. Addition of the vegetable formula succeeded to partially modulate the mineral concentration in blood plasma and this, in turn, assist the process of bone formation. This proves that the vegetable formula is needed and imposes benefit to the body.

It has been reported that phosphorus and calcium contribute to bone development by inhibiting bone resorption [40]. Zn stimulates osteoblasts and inhibits osteoclasts [41]. Mg is important in matrix and mineral metabolism in bone [42].

Table 2: Identification of some phytochemical in the formula using HPLC

\begin{tabular}{ll}
\hline The compound & $\mathbf{m g} / \mathbf{1 0 0} \mathbf{g}$ dry weight \\
\hline Protocatechuic acid & 9.12 \\
Vanillic acid & 1.62 \\
Coumarin & 1.84 \\
Rosmarinic acid & 11.28 \\
Cinnamic & 1.84 \\
Ferulic acid & 1.67 \\
Chrysin & 1.16 \\
Sinapic acid & 2.29 \\
\hline
\end{tabular}

HPLC: High-performance liquid chromatography

Table 3: Chemical analysis of serum of supplemented rats

\begin{tabular}{llll}
\hline Plasma levels & NOVXC & OVXT & OVXC \\
\hline Calcium (mg/dl) & $9.0 \pm 0.3^{\mathrm{a}}$ & $7.52 \pm 0.5^{\mathrm{b}}$ & $7.1 \pm 0.3^{\mathrm{b}}$ \\
Phosphorus (mg/dl) & $3.5 \pm 0.14^{\mathrm{a}}$ & $3.5 \pm 0.17^{\mathrm{a}}$ & $3.3 \pm 0.14^{\mathrm{a}}$ \\
Magnesium (mg/dl) & $1.78 \pm 0.05^{\mathrm{a}}$ & $1.70 \pm 0.01^{\mathrm{a}}$ & $1.22 \pm 0.05^{\mathrm{b}}$ \\
Zinc $(\mu \mathrm{d} / \mathrm{dL})$ & $120 \pm 6.05^{\mathrm{a}}$ & $117.1 \pm 7.1^{\mathrm{a}}$ & $84.1 \pm 6.5^{\mathrm{b}}$ \\
Glucose (mg/dl) & $65 \pm 0.05^{\mathrm{a}}$ & $53.06 \pm 0.96^{\mathrm{b}}$ & $73.18 \pm 0.71^{\mathrm{a}}$ \\
MDA (mMol/L) & $1.95 \pm 0.11^{\mathrm{a}}$ & $6.26 \pm 0.07^{\mathrm{b}}$ & $8.58 \pm 0.06^{\mathrm{c}}$ \\
TAC (nMol/L) & $6.02 \pm 0.11^{\mathrm{a}}$ & $5.52 \pm 0.12^{\mathrm{b}}$ & $3.62 \pm 0.05^{\mathrm{c}}$ \\
Cholesterol (mg/dl) & $67.63 \pm 2.07^{\mathrm{a}}$ & $76.01 \pm 0.77^{\mathrm{b}}$ & $143.0 \pm 2.5^{\mathrm{c}}$ \\
LDL (mg/dl) & $30.00 \pm 1.77^{\mathrm{a}}$ & $75.8 \pm 2^{\mathrm{b}}$ & $106.75 \pm 1.6^{\mathrm{c}}$ \\
HDL (mg/dl) & $22.75 \pm 1.05^{\mathrm{a}}$ & $46.1 \pm 3^{\mathrm{b}}$ & $33.8 \pm 3.5^{\mathrm{c}}$ \\
Triglyceride (mg/dl) & $76.13 \pm 3.96^{\mathrm{a}}$ & $125.8 \pm 10.5^{\mathrm{b}}$ & $74.00 \pm 4.5^{\mathrm{c}}$ \\
\hline
\end{tabular}

MDA: Malondialdehyde, LDL: Low-density lipoprotein, HDL: High-density

lipoprotein, TAC: Total antioxidant capacity
The blood sugar level showed a slight increase in OVXC versus NOVXC rats. Alterations in bone and mineral metabolism were reported in some studies as a result of elevated blood sugar [43] which is accompanied with oxidative stress and partly contributing to the development of osteoporosis [44]. Supplementation with the vegetable formula, in OVXT group, showed hypoglycemic effect. Some studies have similarly shown that eating vegetable significantly reduced blood glucose levels [45,46]. They referred this to its high content of phenolic compounds which act as insulin such as molecules or insulin secretagogues [47]. It is worthy to mention that the oxidative stress of OVXC rats was high as evidenced by the high level of serum MDA and the low value of TAO capacity. Such complication was ameliorated when rats (OVXT) were given the vegetable formula which again confirms its high nutritive and antioxidant power mentioned above. Earlier studies mentioned that cauliflower has high antioxidant power where it contains vitamins (A and C), minerals (calcium, iron, and phosphorous), and traces (zinc and selenium) [48]. In the same time, turnip tops exhibit a high polyphenols content and a good antiradical activity where, flavonoids (isorhamnetin, kaempferol, and quercetin glycosides), hydroxycinnamic derivatives, and isorhamnetin glycosides were identified [12].

A. сера L. has been reported to have antioxidant properties. It contains polyphenols, flavonoids, kaempferol, quercetin, and their glycosides [13]. Spinach is also rich in polyphenols, flavonoids, steroids, and carotenoids, glycosides (such as coumarins, anthraquinones) which were shown to possess anti-inflammatory and antioxidant property [49]. In the same time, soya bean phytochemicals such as total phenols, tannins, and proanthocyanidins showed positive linear correlation to antioxidant activity [14].

Concerning lipid parameters, ovariectomy caused a sharp increase in serum cholesterol, LDL of OVXC versus NOVXC rats (Table 3). It is known that ovarian cells withdraw plasma lipid to synthesize steroids, in turn, lipids are expected to be saved, and its level in blood is increased [50] therefore, postmenopausal women may be at a higher risk for coronary heart disease [51]. Phytoestrogens present in the given formula produce effects similar to those of estrogen so it may control the level of blood lipids to some extent.

\section{CONCLUSION}

It could be concluded that ovariectomy in rat model cause deterioration of bone and elevated expression of bone resorption RANKl, feeding current vegetable formula opposed this effect and was good for health as antioxidant, hypoglycemic, and hypolipidemic. It should be given for longer time to show a better protective effect from bone deterioration.

\section{AUTHOR CONTRIBUTION}

El Shobaky, the senior author, has defined the kinds of vegetables that was proposed to have positive effect on bone formation. Seham was the author who collected and prepared the feed materials and was responsible for animals feeding for 2 months. Emtenan and Moetazza carried out the surgical operation for all ovarectomized rats. they also sacrificed rats and collected blood samples, prepared the gene primers and carried out the RNA extraction and quantified the gene expression. Zeinab, Madeha and Ibrahim Badawy took part in the clinical analysis and identification of the plants phytochemicals. Editing and justification of the paper was by Emtenan Hanfi.

\section{CONFLICT OF INTERESTS}

There is no conflict of interests between authors.

\section{REFERENCES}

1. Jiang E, Wang Z, Meng Q, Li S, Wang F, Shao G, et al. Study on bone density at various skeletal site for the diagnosis of primary osteoporosis. Cell Biochem Biophys 2012;64:1-3.

2. Laughlin GA, Yen SS. Nutritional and endocrine-metabolic aberrations 
in amenorrheic athletes. J Clin Endocrinol Metab 1996;81:4301-9.

3. Anderson MA, Maraskovsky E, Billingsley WL, Dougall WC, Tometsko ME, Roux ER, et al. A homologue of the TNF receptor and its ligand enhance T-cell growth and dendritic-cell function. Nature 1997;390:175-9.

4. Malyankar UM, Scatena M, Suchland KL, Yun TJ, Clark EA, Giachelli CM. Osteoprotegerin is an alpha vbeta 3-induced, NFkappa B-dependent survival factor for endothelial cells. J Biol Chem 2000;275:20959-62.

5. Fuller K, Wong B, Fox S, Choi Y, Chambers TJ. TRANCE is necessary and sufficient for osteoblast-mediated activation of bone resorption in osteoclasts. J Exp Med 1998;188:997-1001.

6. Spelsberg TC, Subramaniam M, Riggs BL, Khosla S. The actions and interactions of sex steroids and growth factors/cytokines on the skeleton. Mol Endocrinol 1999; 13:75-81.

7. Kimble RB, Bain S, Pacifici R. The functional block of TNF but not of IL-6 prevents bone loss in ovariectomized mice. J Bone Miner Res 1997; 12:935-41.

8. Varacallo MA, Fox EJ. Osteoporosis and its complications. Med Clin North Am 2014;98:817-31, xii-xiii.

9. Udomsuk L, Juengwatanatrakul T, Putalun W, Jarukamjorn K. Bimodal action of miroestrol and deoxymiroestrol, phytoestrogens from Pueraria candollei var. Mirifica, on hepatic CYP2B9 and CYP1A2 expressions and antilipid peroxidation in mice. Nutr Res 2012;32:45-51.

10. Tempfer CB, Bentz EK, Leodolter S, Tscherne G, Reuss F, Cross HS. Phytoestrogen in clinical practice: A review of the literature. Fertil Steril 2007;87:1243-9.

11. Price ML, Van-Scoyo CS, Butter LG. Cacao and hocholate flavonoids: Implication for cardiovascular health. J Am Diet Assoc 1978;103:215-23.

12. Romani A, Vignolini P, Isolani L, Ieri F, Heimler D. HPLC-DAD/MS characterization of flavonoids and hydroxycinnamic derivatives in turnip tops (Brassica rapa L. Subsp. Sylvestris L.). J Agric Food Chem 2006;54:1342-6.

13. Prakash D, Singh B, Upadhyay G. Antioxidant and free radical scavenging activities of phenols from onion (Allium cepa). Food Chem 2007;102:1389-93

14. Malencic D, Maksimovic Z, Popovic M, Miladinovic J. Polyphenol contents and antioxidant activity of soybean seed extracts. Bioresour Technol 2008;99:6688-91.

15. Basu P, Sunny SH, Maier C. Estrogenic and antiestrogenic activities of commercial dietary supplements containing herbal ingredients and isoflavones. Int J Pharm Pharm Sci 2016;8-11:307-12.

16. AOAC. AOAC Associatin of Analytical Chemistry of Analysis. $15^{\text {th }}$ ed. Washington, DC: AOAC; 1990.

17. Zilic S, Serpen A, Akillioglu G, Jankovic M, Gokmen V. Distribution of phenolic compounds, yellow pigments and oxidative enzymes in wheat grains and their relation to antioxidant capacity of bran and debranned flour. J Cereal Sci 2012;56:652-8.

18. Thaipong K, Boonorakob U, Crosby K, Cisneros-Zeviios L, Byrne DH. Comparison of ABTS, DPPH, FRAP and ORAC assays for estimating antioxidant activity from guava fruit extracts. J Food Compost Anal 2006;19:669-75.

19. Khajuria DK, Razdan R, Mahapatra DR. Description of a new method of ovariectomy in female rats. Rev Bras Reumatol 2012;52:462-70.

20. Ripoll JP. Colorimetric determination of calcium in serum using methylthymol blue. Clin Chim Acta 1976;72:133-9.

21. Fiske CH, Subbarow YJ. The colorimetric determination of phosphorus. Biol Chem 1925;66:375-400.

22. Smith AJ. A colorimetric method for the estimation of serum magnesium. Biochem J 1955;60:522-7.

23. Hayakawa R, Jap J. Estimation of zinc. Toxic Environ Health 1961;8:14-8.

24. Henery NC. Clinical Chemistry Principles and Techniques. $3^{\text {rd }}$ ed. England: Harber and Row Publishers; 1981.

25. Assmann G, Jabs HU, Kohnert U, Notle W, Schriewer H. LDLcholesterol determination in blood serum. Following precipitation of LDL with polyvinyl-sulfate. Clin Chim Acta 1984;10:77-83.

26. Warnick GR, Benderson V, Albers N. Selected methods of enzymatic analysis. Lin Chem 1983;10:91-9.

27. Fossati P, Prinicip L. Serum triglycerides determined colorimetrically with an enzyme that produces hydrogen peroxide. Clin Chem 1982;28:2077-80.

28. Satoh K. Lipid peroxide (malondialdehyde) colorimetric methods. Clin Chem Acta 1987;90:37.

29. Koracevic D, Koracevic G. Measurement of total antioxidant capacity. J Clin Pathol 2001;54:356-61.

30. Available from: http://www.Glory Bioscience.com

31. RNA Extraction Kit. Available from: http://www.interchim.fr/ft/H/ HH2640.pdf.

32. CDNA. Available from: http://www.jenabioscience.com.

33. Koichiro T, Takamitsu I, Shintaro N, Shinya M, Mingguo H, Kazuyuki N, et al. Inhibition of the RANK/RANKL signaling with osteoprotegerin prevents castration-induced acceleration of bone metastasis in castration-insensitive prostate cancer. Cancer Lett 2017;397:103-10.

34. Li X, Ominsky MS, Stolina M, Warmington KS, Geng Z, Niu QT. Increased RANK ligand in bone marrow of orchiectomized rats and prevention of their bone loss by the RANK ligand inhibitor osteoprotegerin. Bone 2009;45:669-76.

35. Pocock VJ, Sales GD, Milligan SR. Comparison of the oestrogenic effects of infant milk formulae, oestradiol and the phytoestrogen coumestrol delivered continuously in the drinking water to ovariectomised mice. Food Chem Toxicol 2002;40:643-51.

36. Rao LG, Kang NN, Rao AV. Lycopene and other antioxidants in the prevention and treatment of osteoporosis in postmenopausal women. Aging 2014;24:247-58.

37. Rachna S, Preeti S, Pradeep K, Gaurav G. Role of magnesium in postmenopausal women with osteoporosis and osteopenia. Asian J Pharm Clin Res 2016;9:198-9.

38. Okyay E, Ertugrul C, Acar BA, Sisman R, Onvural B, Ozaksoy D. Comparative evaluation of serum levels of main minerals and postmenopausal osteoporosis. Maturitas 2013;76:320-5.

39. Takeuchi I, Kobayashi SH, Hida Y, Makino K. Estradiol-loaded PLGA nanoparticles for improving low bone mineral density of cancellous bone caused by osteoporosis: Application of enhanced charged nanoparticles with iontophoresis. Colloids Surf B Biointerfaces 2017;155:35-40.

40. Prentice A, Schoenmakers I, Laskey MA, Bono S, de Ginty F, Goldberg GR. Nutrition and bone growth and development. Proc Nutr Soc 2006;65:348-60.

41. D'Amelio P, Cristofaro MA, Tamone C, Morra E, Di Bella S, Isaia G, et al. Role of iron metabolism and oxidative damage in postmenopausal bone loss. Bone 2008;43:1010-5.

42. Yamaguchi M. Role of nutritional zinc in the prevention of osteoporosis. Mol Cell Biochem 2010;338:241-54.

43. Seino Y, Ishida H. Diabetic osteopenia: Pathophysiology and clinical aspects. Diabetes Metab Rev 1995;11:21-35.

44. Liu J, Yang J. Uncarboxylated osteocalcin inhibits high glucoseinduced ROS production and stimulates osteoblastic differentiation by preventing the activation of PI3K/Akt in MC3T3-E1 cells. Int J Mol Med 2016;37:173-81.

45. Liu S, Serdula M, Janket SJ, Cook RN, Sesso HW, Willett WC, et al. A prospective study of fruit and vegetable intake and the risk of Type 2 diabetes in women. Diabetes Care 2004;27:2993-6.

46. Dongare S, Rajendran SH, Senthilkumari S, Gupta SK, Mathur R, Saxena $\mathrm{R}$, et al. Genistein alleviates high glucose induced toxicity and angiogenesis in cultured human RPE cells. Int J Pharm Pharm Sci 2015;7-8:294-8

47. Jayaprakasam B, Vareed SK, Olson LK, Nair G, Muraleedharan K. Insulin secretion by bioactive anthocyanins and anthocyanidins present in fruits. J Agric Food Chem 2005;53:28-31.

48. Owen FR. Food Chemistry. $3^{\text {rd }}$ ed. New York, NY, USA: Marcel Dekkar; 1996.

49. Ergene A, Guler PS, Tan S, Mirici E, Hamzaoglu S, Duran A. Antimicrobial and antifungal activity of Heracleum sphondylium sub sp. Artivinense. Afr J Biotechnol 2006;5:1087-9.

50. Gordon T, Kannel WB, Hjortland MC, McNamara PM. Menopause and coronary heart disease. The Framingham study. Ann Intern Med 1978;89:157-61.

51. Matthews KA, Meilahn E, Kuller LH, Kelsey SF, Caggiula AW, Wing RR. Menopause and risk factors for coronary heart disease. N Engl J Med 1989;321:641-6. 